\title{
Anabases
}

ANABASES Traditions et réceptions de l'Antiquité

\section{Présences françaises à Rome : à la recherche de la culture antique}

\section{Philippe Foro}

\section{(2) OpenEdition}

1 Journals

Édition électronique

URL : http://journals.openedition.org/anabases/3107

DOI : 10.4000/anabases.3107

ISSN : 2256-9421

Éditeur

E.R.A.S.M.E.

\section{Édition imprimée}

Date de publication : 1 mars 2007

Pagination : 103

ISSN : 1774-4296

\section{Référence électronique}

Philippe Foro, «Présences françaises à Rome : à la recherche de la culture antique », Anabases [En ligne], 5 | 2007, mis en ligne le 01 janvier 2012, consulté le 21 octobre 2019. URL : http:// journals.openedition.org/anabases/3107 ; DOI : 10.4000/anabases.3107

Ce document a été généré automatiquement le 21 octobre 2019.

(c) Anabases 


\title{
Présences françaises à Rome : à la recherche de la culture antique
}

\author{
Philippe Foro
}

1 Les Français entretiennent avec la ville de Rome des relations particulières, parfois contradictoires, souvent passionnées. Que la découverte de la Ville se fasse à trentetrois ans pour Stendhal ou à soixante-six ans pour Julien Gracq, en groupes tels les étudiants et les pèlerins ou individuellement à l'image de l'abbé Pierre Froment, personnage de Zola dans le roman Rome, elle ne laisse pas indifférent et a toujours une signification. Fils de l'Église ou libéraux anti-cléricaux, les Français viennent à Rome à la recherche d'une histoire disparue, d'une culture encore proche, d'une spiritualité toujours vive. Écrivains, artistes, fonctionnaires napoléoniens à une époque où, selon les mots de Chateaubriand, "les Français de l'Empire eurent à réparer les ravages qu'avaient faits les Français de la République», prélats, tous eurent dans l'Urbs une confrontation avec l'Antiquité et sa culture, païenne et chrétienne. Qu'ils soient célèbres (Montaigne, Chateaubriand), connus des spécialistes (de Brosses, Carcopino) ou anonymes, que visitaient les Français à Rome? Qu'étudiaient-ils? Quels regards portaient-ils sur les vestiges antiques dans une cité, véritable «royaume de pierres » selon l'expression de Dominique Fernandez à propos du Forum? Que venaient-ils chercher pour l'esprit dans une Rome magnifiée ou décevante?

\section{AUTEUR}

\section{PHILIPPE FORO}

Université de Toulouse II-Le Mirail 
UFR d'Histoire, Arts et Archéologie

philippe.foro@wanadoo.fr 